American Journal of Applied Sciences 9 (3): 376-381, 2012

ISSN 1546-9239

(C) 2012 Science Publications

\title{
A Quantity Survey of Halon 1301
}

\author{
Supat Patvichaichod \\ Department of Mechanical Engineering, \\ Faculty of Engineering at Si Racha, \\ Kasetsart University, Si Racha Campus, \\ 199 Sukhumvit Road, Chonburi, 20230, Thailand
}

\begin{abstract}
Problem statement: The objectives of this article were to survey the data of Halon 1301 user in Thailand in which the data was used to establish the guidelines of Halon management project. Approach: The data survey of Halon 1301 user began by sending a questionnaire to 3,756 organizations that were expected to use Halon 1301, total number of replied organizations is 2,627 organizations, which is $70 \%$ of all organizations that received the questionnaire. There are 31 organizations of Halon 1301 users and there are 17 organizations, which ever used Halon 1301. Results: Total quantity of Halon 1301 is $50,381.32 \mathrm{~kg}$. The number of small size users is zero. The number of medium size users is 6 organizations. The quantity of Halon 1301 is $947.92 \mathrm{~kg}$. The number of large size users is 24 organizations. The quantity of Halon 1301 is $49,433.4 \mathrm{~km}$. For the phase-out users, the total quantity used by organizations is $28,741.6 \mathrm{~kg}$. In case the category is divided by the size of organization, the small size phase-out user is 2 organizations. Total Halon 1301 quantity used in the organization is $81.7 \mathrm{~km}$. The medium size phase-out user is 1 organization. Total Halon 1301 quantity used in the organization is $181.2 \mathrm{~km}$. The large size phase-out user is 13 organizations. Total Halon 1301 quantity used in the organization is $28,478.7 \mathrm{~km}$. Conclusion: The Halon quantity that is available in Thailand is $79,122.92 \mathrm{~kg}$, which is divided into (1) the Halon that is currently used by companies in which the quantity is approximately $50,381.32 \mathrm{~kg}$ or $64 \%$ of Halon quantity in the country. Most of users are from industrial factories, which do not have any policy of the adjustment because of the high installation cost. And (2) the phase-out Halon that is still kept in Thailand because there is no organization has an ability to dispose Halon. The Halon quantity in this type is $28,741.6 \mathrm{~kg}$ or $36 \%$ of Halon quantity in the country. The power plant and office buildings are the business that mostly abandoned the use of Halon. Most of phase-out Halon is delivered to supplier for the storage purpose.
\end{abstract}

Key words: National Fire Protection Association (NFPA), storage purpose, designing, installing, aviation purpose, management policies, article presents

\section{INTRODUCTION}

Halon is a suppression agent that is synthesized by human. Halon has a good property in fire suppression with less harm to human health. The popular used of Halon are Halon 1211 (contained in a portable fire extinguisher) and Halon 1301 (contained in a fixed system). However, Halon is an efficient agent to severely deplete the ozone in the atmosphere. The member countries are assigned to reduce and abandon the use of Halon within 2009. Thailand, which is in a developing country group, is assigned to have an imported quantity of Halon to be zero in 2010. The exception of the export is allowed for the essential use only, for examples, for country security and for aviation purpose. From those missions, "the Halon 1301
Management Program in Thailand" was established by receiving a financial support from the Multilateral Fund for the Implementation of the Montreal Protocol.

The main objective of the project is to develop the cooperation between the government sectors and Halon 1301 users in establishing the management policies of Halon 1301 in Thailand. The activities of the project are categorized into 5 parts:

Part1: To manage the training program to the government officer and Halon 1301 user in which the government policy of Halon 1301 and the phase-out plan were informed. The opinions from the Halon 1301 users were also gathered

Part2: To survey the data of Halon 1301 user in Thailand in which the data was used to establish 
the guidelines of Halon management. The Halon 1301 information clearinghouse was also formed as an information center for Halon trading.

Part3: To select the large Halon 1301 user from 20 organizations to receive the support for the implementation plan in Halon 1301 phase-out. In addition, the training program was established for small size user to inform about how to make a phase-out plan

Part4: To select the Halon 1301 user from 12 organizations to be the sample project of the Halon 1301 phase-out. The selected organizations were received the support for all processes until the alternative system is completely installed. The certain amount of funding was provided in changing the fire suppression system.

Part5: To inform the knowledge about Halon management, government policies and the procedures of the project. The purpose of the information is to inform the Halon 1301 user, the government sector and the public about the necessary of the Halon 1301 phase-out

This article presents the data survey of Halon 1301 user in Thailand for Part 2 of the Halon Management Program in Thailand. A lot of related articles that involve in Halon management and data survey such as McDougal and Dodd (1993); Morehouse (1993); McCulloch (1999); Rubenstein (1993); Abramson et al. (2006); Takemura (2010) and Chinnaraj et al. (2011).

\section{MATERIALS AND METHODS}

History of halon extinguishing agents: The first type of Halon ever used by human is Halon 104, which was developed in 1907 in the form of portable fire extinguisher. The Halon 104 was widely used in various industries because of the property of low electrical conductivity. The Halon 104 was found to be a cause of human death, then Halon 104 was abolished in 1950.

The next type of Halon that was developed in 1920 is Halon 1001. The Halon 1001 has more efficiency in fire suppression than Halon 104. However, the Halon 1001 has more toxicant on human. The Halon 1001 in the form of portable fire extinguisher is unpopular. The Halon 1001 was widely used in the war aircraft and warship by the United Kingdom and Germany in the World War II. The Halon 1011 was developed during 1960s after the Halon 1001 was out-of-date. Only Halon 1011 was used in the explosion suppression system during those periods.
In 1947, various organizations incorporated the development of Halon that has less toxicant on human by 4 types, which are Halon 1202, Halon 1211, Halon 1301 and Halon 2402. Among these Halon, the Halon 1201 is the most efficient agent in fire suppression but has the most toxic on human. So the Halon 1201 is unpopular. The Halon 1301 has the efficiency in fire suppression in the second place that is less toxic on human, so the Halon 1301 is widely used. For Halon 1211, the agent has lower ability in evaporation than Halon 1301. So the Halon 1211 portable fire extinguisher becomes popular to industries.

Until 1966, the National Fire Protection Association (NFPA) issued "the NFPA 12A: Standard on Halon 1301 Fire Extinguishing System", which provides the advanced rules for designing, installing and maintaining the agent systems. So Halon 1301 is widely used with this standard.

In 1992, the NFPA issued "the NFPA 2001: Standard on Clean Agent Fire Extinguishing Systems". This standard provides the information of designing, installing and maintaining the fire suppression system instead of Halon. During this period, the Halon becomes out-of-date.

The data survey in Thailand is found that the beginning of the Halon 1301 was in 1853. The Halon 1301 has been widely used during 1987-1992. The survey is also found that the last organization, in which the Halon 1301 was installed, was in 1995 where the Halon was installed in the old machines delivered from Japan.

Procedures of the data survey: To survey the data of Halon 1301 user in Thailand, the author divided the categories of organizations that are expected to be Halon 1301 user. The 9 categories of organizations are shown in Table 1. The data survey of Halon 1301 user begins by sending a questionnaire to 3,756 organizations that are expected to use Halon 1301, total number of replied organizations is 2,627 organizations, which is $70 \%$ of all organizations that are received the questionnaire. There are 31 organizations of Halon 1301 users and there are 17 organizations, which ever used Halon 1301. The relevant data is shown in Table 2.

Table 1: Categories of organizations that are received the questionnaire of the data survey of Halon 1301 user

\begin{tabular}{ll}
\hline Category & Remarks \\
\hline Museum & Both of government and private sector \\
Military sector & All military units \\
Government sector & - \\
Airlines & Both of government and private sector \\
Bank & Both of government and private sector \\
Hospital & Both of government and private sector \\
Power plant & Both of government and private sector \\
Industrial factory & Both inside and outside industrial estate \\
Office buildings & In Bangkok Metropolitan Area \\
\hline
\end{tabular}


Am. J. Applied Sci., 9 (3): 376-381, 2012

Table 2: Conclusion of data collection for the Halon 1301 user

\begin{tabular}{|c|c|c|c|c|c|}
\hline Category & $\begin{array}{l}\text { Number of } \\
\text { Organization } \\
\text { Participated } \\
\text { the survey }\end{array}$ & $\begin{array}{l}\text { Number of } \\
\text { organizations } \\
\text { replied the } \\
\text { questionnaire }\end{array}$ & $\begin{array}{l}\text { Number of } \\
\text { organizations } \\
\text { are using } \\
\text { Halon } 1301\end{array}$ & $\begin{array}{l}\text { Number of } \\
\text { organizations } \\
\text { had ever used } \\
\text { Halon } 1301\end{array}$ & $\begin{array}{l}\text { organizations } \\
\text { organizations } \\
\text { have never used } \\
\text { Halon } 1301\end{array}$ \\
\hline Museum & 50 & $44(88 \%)$ & 1 & 1 & 42 \\
\hline $\begin{array}{l}\text { Military } \\
\text { sector }\end{array}$ & 28 & $1(4 \%)$ & 1 & 0 & 0 \\
\hline $\begin{array}{l}\text { Government } \\
\text { sector }\end{array}$ & 38 & $12(32 \%)$ & 0 & 1 & 11 \\
\hline Airlines & 8 & $5(63 \%)$ & 1 & 0 & 4 \\
\hline Bank & 31 & $26(84 \%)$ & 6 & 4 & 21 \\
\hline Hospital & 270 & $223(83 \%)$ & 0 & 0 & 223 \\
\hline Power plant & 90 & $77(83 \%)$ & 1 & 5 & 71 \\
\hline $\begin{array}{l}\text { Industrial } \\
\text { factory }\end{array}$ & 2,800 & $1,948(70 \%)$ & 17 & 2 & 1929 \\
\hline $\begin{array}{l}\text { Office } \\
\text { buildings }\end{array}$ & 441 & $291(66 \%)$ & 4 & 4 & 283 \\
\hline Total & 3,756 & $2,627(70 \%)$ & 31 & 17 & 2,584 \\
\hline
\end{tabular}

From a statistical theory of population and sample size selection, the sample size will be determined by the following criteria:

- Population size is approximately a hundred, a sample size of $15-30 \%$ is used

- Population size is approximately a thousand, a sample size of $10-15 \%$ is used

- Population size is approximately a ten thousand, a sample size of $5-10 \%$ is used

- From Table 2 showed that all types of organizations, except the military sector, have a sample size (organizations that provide the data) more than $30 \%$. This means the sample size data can be considered as a representation of a population

In the data survey of Halon 1301 user from 31 organizations, total quantity of Halon 1301 is 50,381.32 $\mathrm{kg}$. The necessary user is found only the Naval Science Department, the Royal Thai Navy. This department has the duty for the country's security. Total quantity used is $13,414 \mathrm{~kg}$, which is $27 \%$ of total quantity. There are 30 unnecessary Halon 1301 users, which used $73 \%$ of total quantity. There are 17 organizations in which the Halon 1301 system has been removed. The total quantity used is $28,741.6 \mathrm{~km}$.

\section{RESULTS}

Data of Halon 1301 user: Total quantity of Halon 1301 is $50,381.32 \mathrm{~kg}$. The number of small size users is zero (maintain Halon 1301 less than $60 \mathrm{~kg}$ ). The number of medium size (maintain Halon 1301 between $60-200 \mathrm{~kg}$ ) users is 6 organizations. The quantity of Halon 1301 is $947.92 \mathrm{~kg}$. The number of large size (maintain Halon 1301 more than $200 \mathrm{~km}$ ) users is 24 organizations.

The quantity of Halon 1301 is $49,433.4 \mathrm{~kg}$. The results are shown in Fig. 1 and 2.

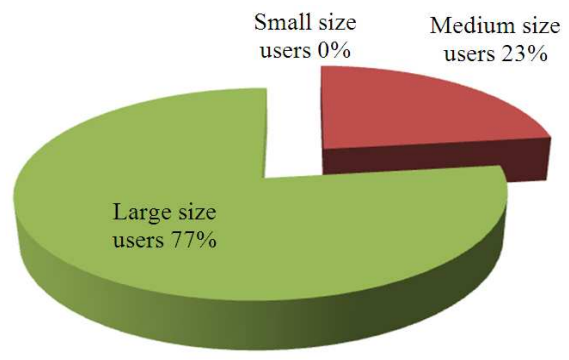

Fig. 1: Depicts the pie chart showing the number of Halon 1301 users by size of user

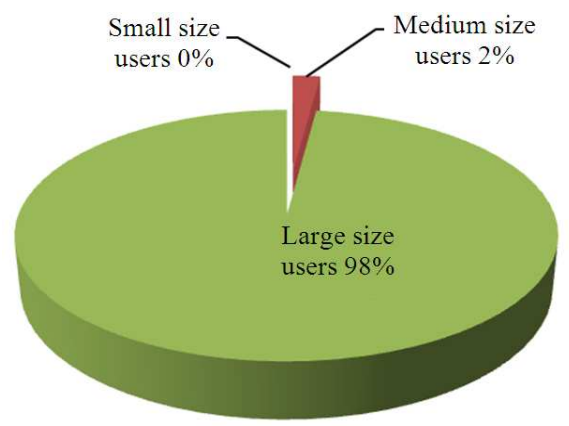

Fig. 2: Depicts the pie chart presenting the quantity of Halon 1301 by the size of user

From Fig. 1 and 2, the number of medium size users is $23 \%$ and the number of large size users is $77 \%$. The quantity of medium size users is $2 \%$ and the quantity of large size users is $98 \%$.

If the number of user categorized by size, the 8th category of industrial factory has the largest number of Halon 1301 user, which has 17 organizations or $55 \%$. For the 5th category of Bank, the number of Halon 1301 user is 6 organizations or $20 \%$. In case of the 3rd category of government sector and the 6th category of hospital, there has not got any Halon 1301 user in these categories. The mentioned results are presented in Fig. 3.

If the number of user categorized by size, the 8th category of industrial factory used the largest number of Halon 1301 quantity, which is $24,001.2 \mathrm{~kg}$ or $49 \%$. The 2nd category of military sector used the quantity of $13,414 \mathrm{~kg}$ or $27 \%$. The 3rd category of government sector and the 6th category of hospital used the smallest quantity of Halon 1301, which is zero. The results are shown in Fig. 4.

In case of regions of the country are considered, the most number of Halon 1301 users is in the central part of the country, which is 15 organizations or $48 \%$. The eastern part of the country has 11 organizations of Halon 1301 user or $36 \%$ and the there is no any organization of Halon 1301 user in the western part of the country. The results are concluded in Fig. 5. 


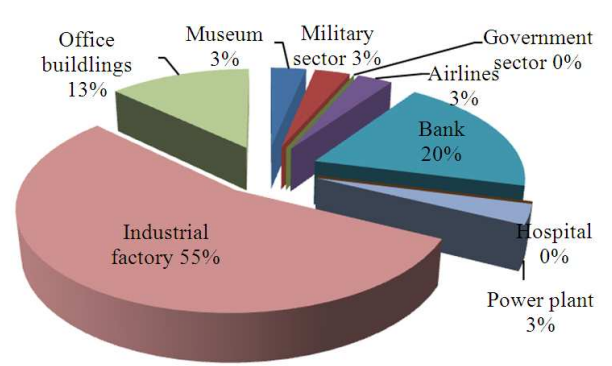

Fig. 3: Depicts the pie chart showing the number of Halon 1301 users by category of user

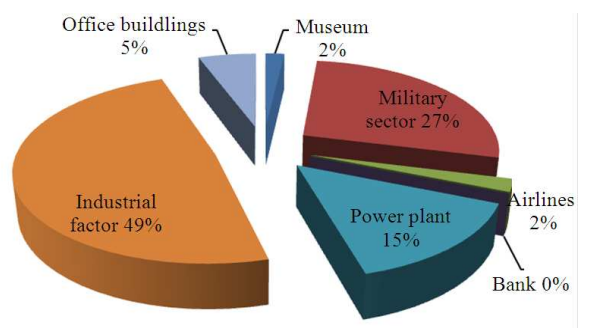

Fig. 4: Depicts the pie chart showing the quantity of Halon 1301 by category of user

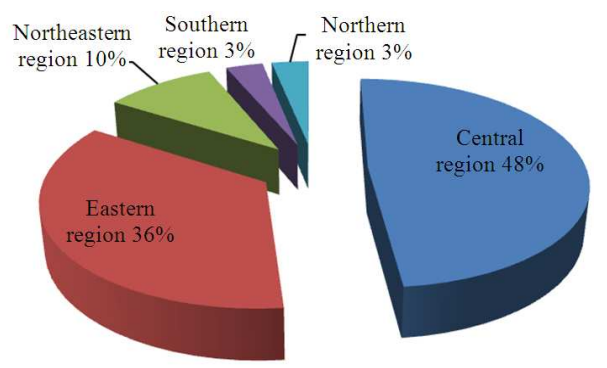

Fig. 5: Depicts the pie chart showing the number of Halon 1301 users by regions

In classifying the quantity of Halon 1301 by regions, the most number of Halon 1301 quantity is in the central part of the country, which is $27,495.02 \mathrm{~kg}$ or $55 \%$. The eastern part used the quantity of $17,900 \mathrm{~km}$ or $36 \%$. The western part of the country used the less quantity of Halon1301, which is zero. The results are shown in Fig. 6.

Data of Halon 1301 phase-out user: The total quantity used by organizations is $28,741.6 \mathrm{~kg}$. In case of the category is divided by the size of organization, the small size phase-out user is 2 organization. Total Halon 1301 quantity used in the organization is 81.7 $\mathrm{km}$. The medium size phase-out user is 1 organization. Total Halon 1301 quantity used in the organization is $181.2 \mathrm{~km}$. The large size phase-out user is 13 organization.

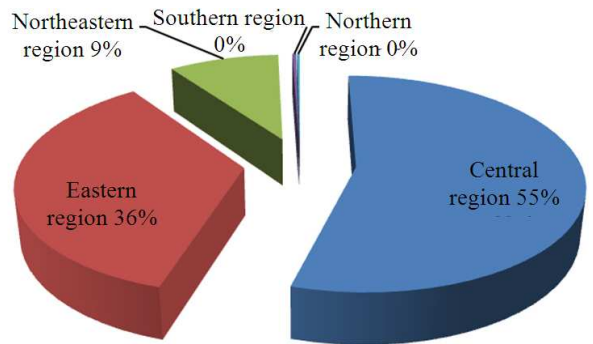

Fig. 6: Depicts the pie chart showing the quantity of Halon 1301 by regions

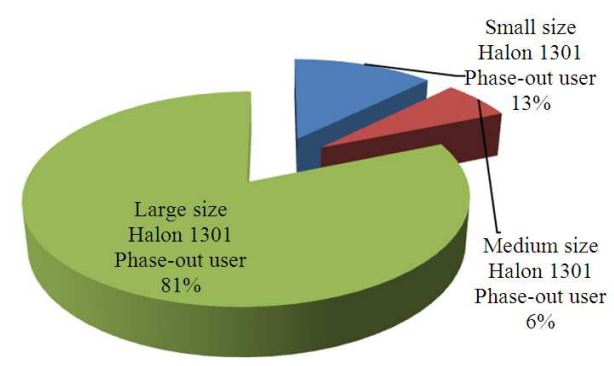

Fig. 7: Depicts the pie chart showing the number of Halon 1301 phase-out user by the size of user

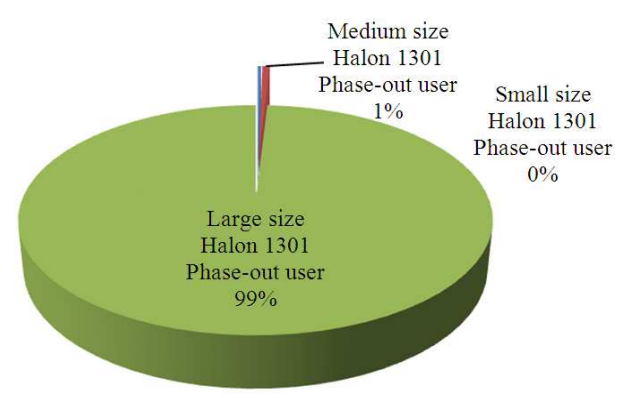

Fig. 8: Depicts the pie chart showing the quantity of Halon 1301 used by the phase-out user categorized by the size of user

Total Halon 1301 quantity used in the organization is $28,478.7 \mathrm{~km}$. The survey results are shown in Fig. 7 and 8.

From Fig. 7 and 8, the number of small and medium size of Halon 1301 users is $19 \%$ and the large size phase-out user is $81 \%$. The number of medium size ohase-out user is $1 \%$. The quantity used by the large size o phase-out users is $99 \%$.

If the data is classified by type of Halon 1301 user, the 7th category of power plant with 5 organizations has the largest quantity of phase-out Halon 1301, which is $29 \%$. The 5th category of bank and the 9th category pf office buildings with 4 organizations uses the $23 \%$ of Halon 1301. The results are shown in Fig. 9. 


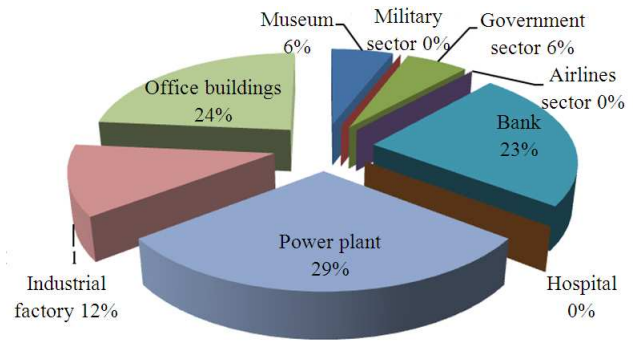

Fig. 9: Depicts the pie chart showing the number of Halon 1301 phase-out user by the categories of users

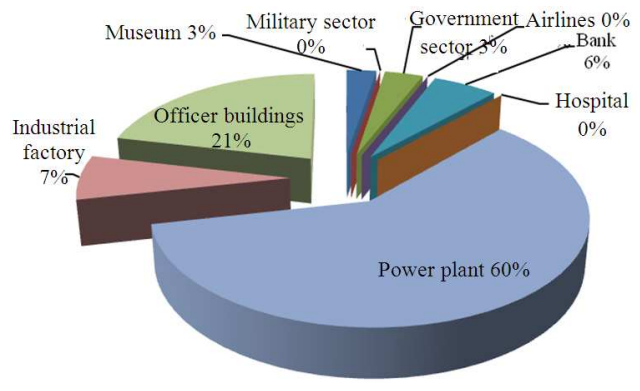

Fig. 10: Depicts the pie chart showing the quantity of Halon 1301 used by the phase-out user categorized by the categories of users

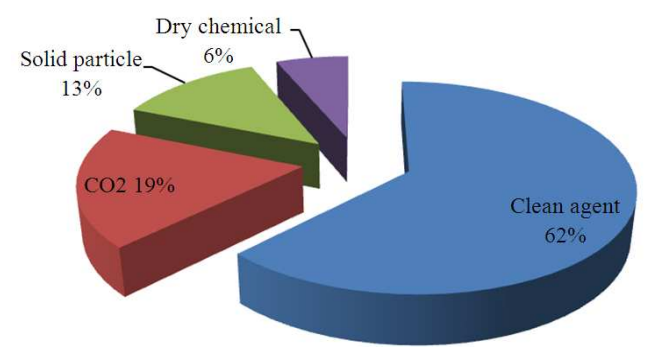

Fig. 11: Depicts a pie chart showing the types of alternative agents selected by organizations

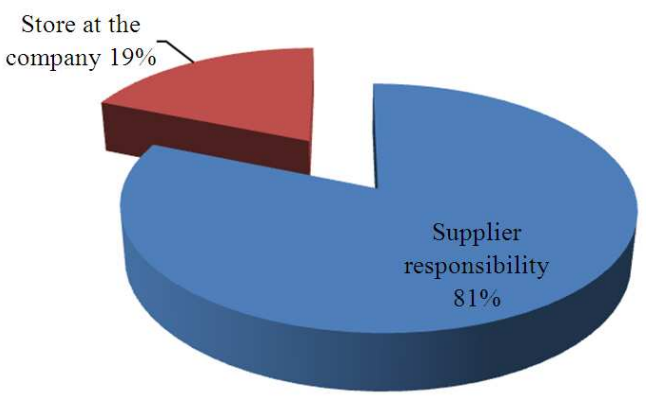

Fig. 12: Depicts a pie chart showing the management methods of phase-out Halon
If the data is classified by quantity of Halon1301, the 7th category of power plant has the largest quantity of phase-out Halon, which is $17,186 \mathrm{~kg}$ or $60 \%$. For 9th category of office buildings, the quantity of phase-out Halon 1301 is $6,160 \mathrm{~kg}$ or $21 \%$. The survey results are shown in Fig. 10.

Most of Halon 1301 phase-out users change to use the clean agent for 10 organizations or $62 \%$. The survey data are shown in Fig. 11 and most of Halon 1301 phase-out users use the company, that installs the clean agent system, manages the phase-out Halon 1301 by $81 \%$ as shown in Fig. 12.

\section{DISCUSSION}

The Trading Sources and Prices of Halon 1301: From the data searching, the organizations in abroad do not purchase the Halon 1301 but accept to destroy the agent in which the cost is rather high. There has not got any organization in Thailand providing the service of Halon 1301 extermination. Only a fire protection suppliers company has a service of purchasing Halon 1301 by the following weight criteria (the company purchases the agent including extinguisher):

- The extinguisher contained with Halon 1301 about $20-50 \mathrm{~kg}$ and the buying price is 3,000 baht per extinguisher

- The extinguisher contained with Halon 1301 about $51-100 \mathrm{~kg}$ and the buying price is 4,000 baht per extinguisher

- The extinguisher contained with Halon 1301 about $101-150 \mathrm{~kg}$ and the buying price is 5,000 baht per extinguisher

- The extinguisher contained with Halon 1301 about $151-200 \mathrm{~kg}$ and the buying price is 7,000 baht per extinguisher

- The extinguisher contained with Halon 1301 more than $200 \mathrm{~kg}$ and the buying price is 8,000 baht per extinguisher

The Operation Obstacles: The obstacles are found during the Halon 1301 data survey as followings:

- From the interview to the military sector about the Halon 1301's donation from the public sector, the conclusion is this operation cannot be accomplished because the pureness of the donated Halon 1301 cannot be tested. The main reason is there has not got a testing equipment of Halon pureness in Thailand 
- $\quad$ Some suppliers of the fire suppression agent do not disclose the quantity data of Halon 1301 for service the customer. So the survey does not cover the possessed Halon 1301 quantity from the suppliers

\section{CONCLUSION}

The Halon quantity that is available in Thailand is $79,122.92 \mathrm{~kg}$, which is divided into (1) the Halon that is currently used by companies in which the quantity is approximately $50,381.32 \mathrm{~kg}$ or $64 \%$ of Halon quantity in the country. Most of users are from industrial factories, which do not have any policy of the adjustment because of the high installation cost. And (2) the phase-out Halon that is still kept in Thailand because there is no organization has an ability to dispose Halon. The Halon quantity in this type is $28,741.6 \mathrm{~kg}$ or $36 \%$ of Halon quantity in the country. The power plant and office buildings are the business that mostly abandoned the use of Halon. Most of phaseout Halon is delivered to supplier for the storage purpose.

The alternative agent of Halon, that is mostly used, is the clean agents. The FM200 and the NAF125 are the clean agents whereas the FM200 is the most popular in Thailand. So the storage of the FM200 in the country is rather high and is convenience to supply to the user. In case of NAF125, the benefit is no requirement to change all previous equipments of Halon1301. So, the installation cost can be saved.

\section{ACKNOWLEDGMENT}

This research was funded by the National Ozone Unit, Department of Industrial Works, Ministry of Industry, Thailand.

\section{REFERENCES}

Abramson, C.I., W. Howard, M. Zolna, S. Nain and I.S. Moraes et al., 2006. A price survey comparison of alcoholic beverages with the five basic food groups in Paraiba, Brazil. J. Soc. Sci., 2: 100-103. DOI: 10.3844/jssp.2006.100.103

Chinnaraj, C., R. Vijayan and P. Govindarajan, 2011. Analysis of Eco friendly refrigerants usage in airconditioner. Am. J. Environ. Sci., 7: 510-514. DOI: 10.3844/ajessp.2011.510.514

McCulloch, A., 1999. CFC and Halon replacements in the environment. J. Fluorine Chem., 100: 163-173. DOI: $10.1016 /$ S0022-1139(99)00198-0

McDougal, J.N. and D.E. Dodd, 1993. Air force approach to risk assessment for Halon replacements. Toxicol. Lett., 68: 31-35. DOI: 10.1016/0378-4274(93)90116-F PMID: 8516772

Morehouse, Jr., E.T., 1993. Overview-air force policy on halons. Toxicol. Lett., 68: 11-19. DOI: 10.1016/0378-4274(93)90113-C

Rubenstein, R., 1993. Human health and environmental toxicity issues for evaluation of halon replacements. Toxicol. Lett., 68: 21-24. DOI: 10.1016/0378-4274(93)90114-D

Takemura, T., 2010. A quantitative study on japanese workers' awareness to information security using the data collected by web-based survey. Am. J. Econ. Bus. Admin., 2: 20-26. DOI: 10.3844/ajebasp.2010.20.26 